\title{
Validating the factors influencing social commerce adoption in small and medium enterprise in malaysia
}

\author{
Walid Abdulla Ali, Muriati Mukhtar, Ibrahim Mohamed \\ Faculty of Information Science and Technology, Universiti Kebangsaan Malaysia (UKM), Malaysia
}

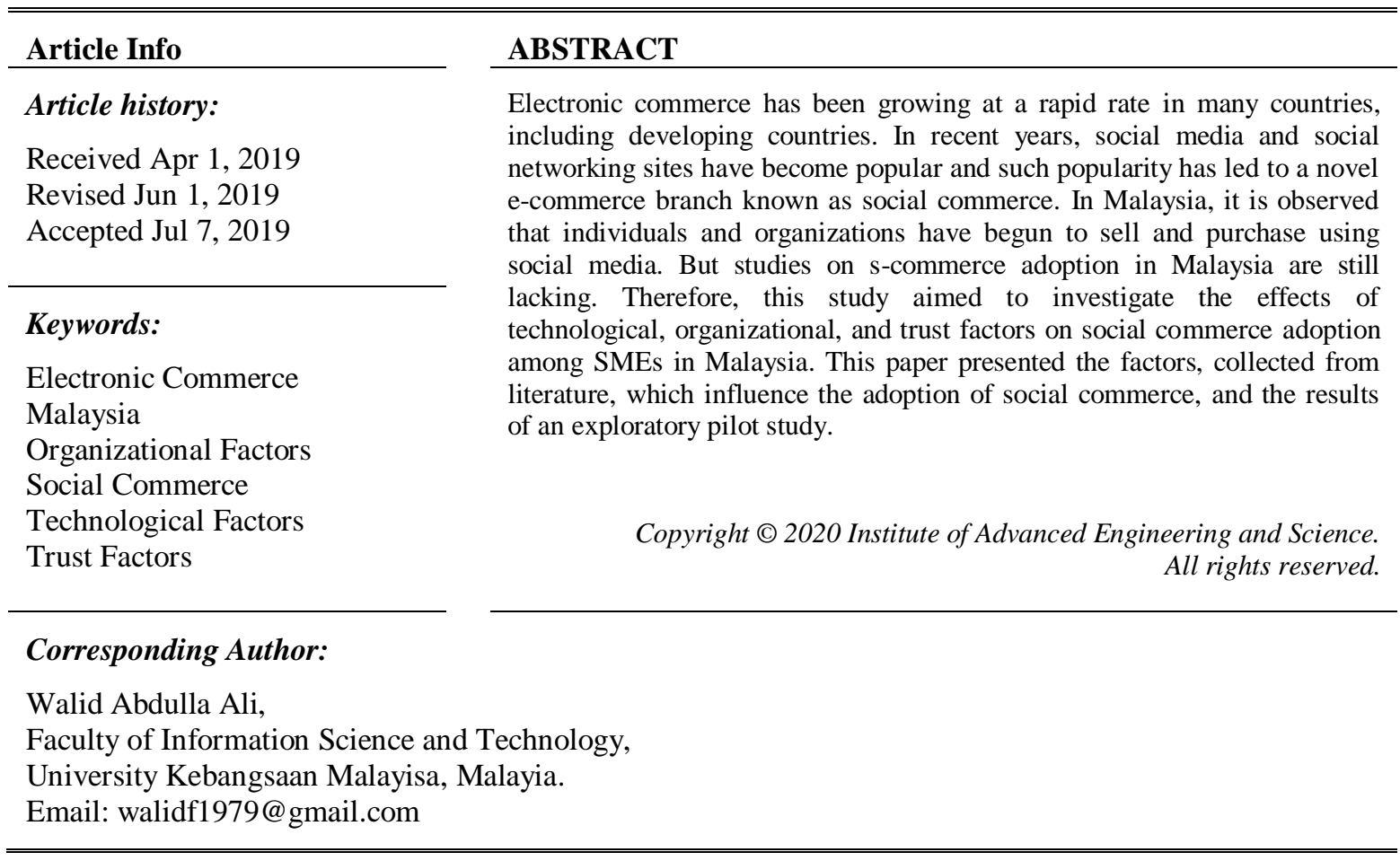

\section{INTRODUCTION}

E-commerce is an emerging and convergence of numerous main information technologies in business practices [1]. Electronic commerce (E- commerce) has been growing in a rapid rate in many countries including developing countries such as Arab and Asia countries. In recent years, the increasing popularity of social media and social networking sites has given rise to a new stream of electronic commerce, called social commerce. Social commerce is a new stream and subset of e-commerce [2]. By combining ecommerce activities with social media, social commerce enables consumers to participate, communicate, and interact in the online selling and buying of products and services. However, many e-commerce companies today are still trying to find out which factors influence consumers to participate in social commerce [3].

E-commerce is dividing into three categories: business to business or B2B (Cisco), business to consumer or B2C (Amazon), and consumer to consumer or C2C (eBay [4].S-commerce is different from ecommerce in terms of organization objectives, customer relationships and system procedures. First, the oganizational goal of e-commerce is to increase efficiency with the strategies used in searchers' one-click purchasing, specification-centered virtual catalogs and recommendations built on the prior shopping pattern of consumers., On the other hand, social commerce is more centered on social goals like networking, cooperation and sharing information, while shopping is only a secondary concern. In respect of customer relations, customers often communicate with e-commerce platforms (individual and independent) from other customers, whereas s-commerce entails online publics supporting social relationship to improve customers' interaction. Moving on to system interaction, e-commerce refers to a classic form of interaction, ysung oneway browsing. In this approach, customer-derived information is seldom made available to businesses or their rivals. However, in social commerce, social and interactive approaches are developed, allowing 
customers to provide their feedback and to make known their thoughts, and share information with their online community and with businesses [5].

Malaysia is among the first countries in Asia to establish a Ministry of e-commerce development and to be the leader in promoting the growth of ICT with the support of several bodies like the Malaysian Communications and Multimedia Commission and Multimedia Development Corporation [6].

The emergence of s-commerce in Malaysia has been an interesting but challenging phenomenon that cannot be ignored. Majority of the people in Malaysia have begun to sell and purchase using social media, but studies on s-commerce are still lacking, SMEs in developing countries still have a low level of IS adoption, it is important to focus on how to enhance the internal infrastructure of these organizations to increase their level of adoption in Malaysia. and what little there is has focused on forecasts, speculations, experiences and status reports on s-commerce in Malaysia [7].

\section{RESEARCH METHOD}

This present study began with a comprehensive review of the literature and compiled a detailed list of variables determined as important factors in the adoption and use of social commerce. On the basis of the literature review, this study investigated the influential variables in the adoption of s-commerce (SC) by enterprises from various aspects. First, SC was viewed as a technological innovation; the study examined SMEs' adoption of SC from an innovation dispersion perspective. Secondly, the success of SC could be influenced by features of the organization itself; therefore, the appropriate trust factors were included in the analysis based on the internal characteristics of the firm. Following a thorough assessment of variables examined earlier, a conceptual model was created (see Figure 1) which facilitated the research direction. The model comprised three aspects of the factors: 1, Technological factors, 2, Organizational factors, and 3, trust factors.

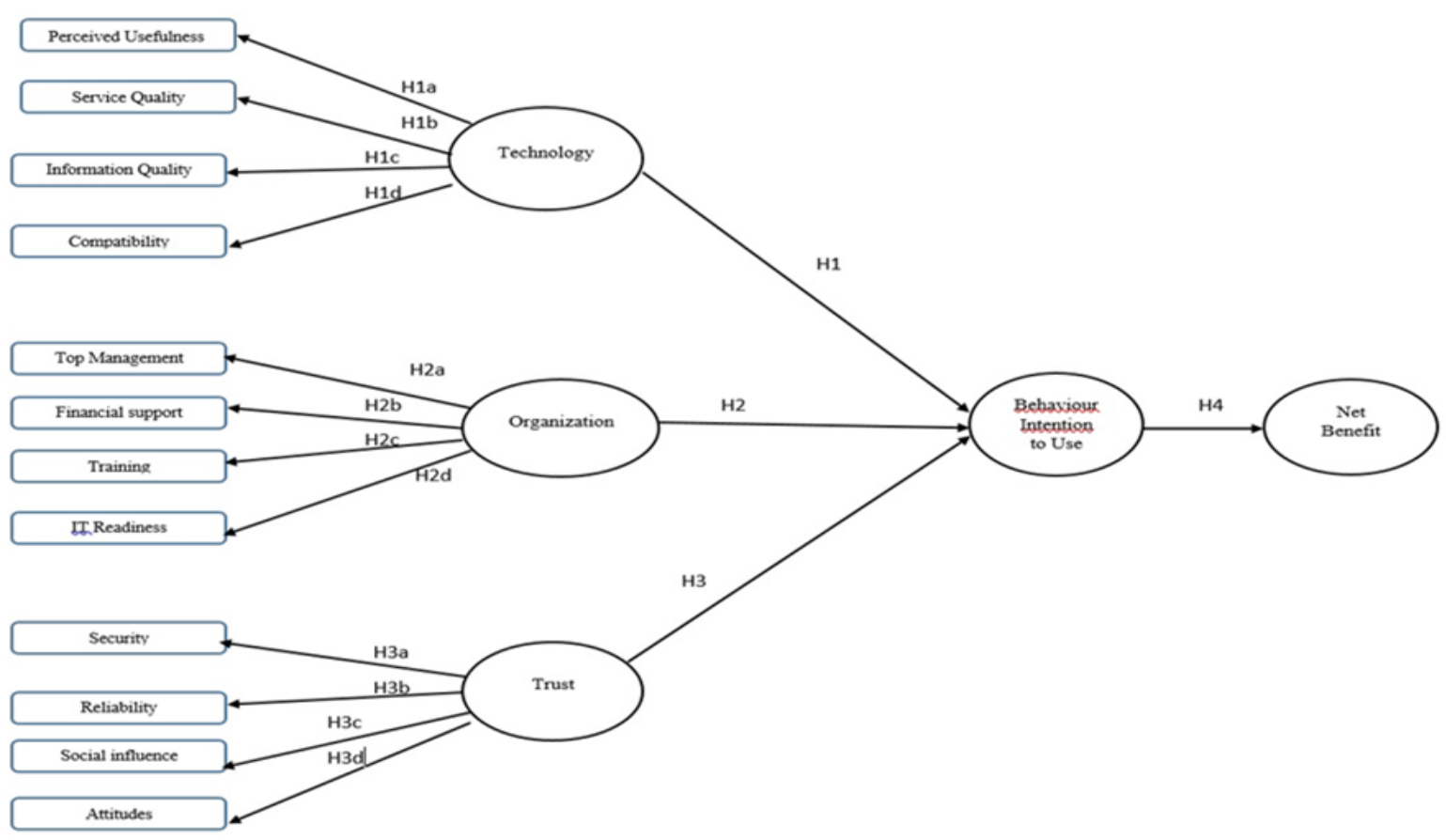

Figure 1. Model of social commerce adoption

H1: Technological factors positively affect the behavioral intention to use SC among SMEs.

$\mathrm{H} 2$ : Organizational factors positively affect the behavioral intention to use SC among SMEs.

H3: Trust factors positively affect the behavioral intention to use SC among SMEs.

H4: Behavioral intention to use SC is closely related to the net benefits of SMEs.

A quantitative research approach was employed in this pilot study. The participants were Malaysian owners and managers of SMEs. The selection of the participants $(\mathrm{N}=200)$ was for the study sample of and done employing random sampling. With regard to he number of the sample, SEM analysis requires the sample to be not less than 100 [8].

Validating the factors influencing social commerce adoption in small and medium ... (Walid Abdulla Ali) 
Furthermore, employing smart PLS path modeling indicates that the sample size to be 30-100 cases. Therefore, 100 respondents were deemed adequate. The questionnaire design was based on prior literature adapted accordingly to suit this study[9].The survey questionnaire employed for collection of the data from the sample was derived from earlier works on social commerce and utilised as presented in Table 1.

The quesrionnaire consists of 67 items adapted by the researchers based on the objectives of the current study. In response to each item, the participant was required to choose one of the five-point Likertscales that ranged from (1) "strongly disagree" to (5), "strongly agree." Copies of the survey questionnaire were disseminated to $100 \mathrm{SME}$ managers in Malaysia online and manually but only 45 returned questionnaires were deemed useful for analysis. The data were analysed wmploying SEM through smart PLS 2 software.

Table 1. Varlables and Itmes

\begin{tabular}{|c|c|c|}
\hline Constructs & Question description & References \\
\hline & I would find the social commerce services system useful in my work job. & \\
\hline \multirow[t]{3}{*}{ Usefulness } & Using social commerce services enables me to accomplish tasks more efficiently. & [11] \\
\hline & Using social commerce services would make it easier to do my job tasks. & \\
\hline & Using social commerce increases my professional performance. & \\
\hline \multirow[t]{5}{*}{ Service quality } & Social commerce understands the specific needs of its users. & \\
\hline & through. & [14] \\
\hline & Sellers on social commerce must always be willing to help customers. & [15] \\
\hline & My overall opinion of the services provided by social commerce is very good. & [16] \\
\hline & The social commerce fits with all aspects of our work & \\
\hline Compatibility & The social commerce is consistent with our company culture. & [14] \\
\hline \multirow{5}{*}{$\begin{array}{l}\text { Information } \\
\text { quality }\end{array}$} & The web site provides updated information. & [18] \\
\hline & It is easy to find the information that I need. & [15] \\
\hline & Overall, I think this s-commerce firm provides useful information. & [19] \\
\hline & The web site provides timely information. & \\
\hline & This s-commerce firm provides reliable information & \\
\hline \multirow{5}{*}{$\begin{array}{l}\text { Top management } \\
\text { support }\end{array}$} & $\begin{array}{l}\text { My top management is likely to consider the adoption of social commerce as strategically } \\
\text { important. }\end{array}$ & {$[20]$} \\
\hline & Top management would support the use of social commerce. & \\
\hline & Top management would provide resources necessary for the adoption of social commerce & [21] \\
\hline & My top management is willing to take risks involved in the adoption of social commerce & \\
\hline & $\begin{array}{l}\text { Our management constantly encourages the employees to use new technologies in their daily work. } \\
\text { Our organization is well-computerized using a local area network }\end{array}$ & \\
\hline IT Readiness & The training gave us confidence in use of cloud computing & [21] \\
\hline \multirow[t]{4}{*}{ Training } & My learning and training is/was useful for online shopping. & [23] \\
\hline & $\begin{array}{l}\text { My level of understanding was substantially improved after going through the training program } \\
\text { on cloud computing. }\end{array}$ & \\
\hline & I have had training to use social commerce and the internet to shop online. & \\
\hline & On social commerce, some people would offer suggestions when I needed help. & \\
\hline \multirow[t]{4}{*}{ Financial support } & $\begin{array}{l}\text { When faced with difficulties, some people on social commerce would help me discover the cause } \\
\text { and provide me with suggestions. }\end{array}$ & $\begin{array}{l}{[24]} \\
{[16]}\end{array}$ \\
\hline & $\begin{array}{l}\text { When I encountered a problem, some people on social commerce would give me information to } \\
\text { help me overcome the problem. }\end{array}$ & [25] \\
\hline & When faced with difficulties, some people on social commerce are on my side with me. & \\
\hline & $\begin{array}{l}\text { I believe the financial information I provide with Social Network will not be manipulated by } \\
\text { inappropriate parties }\end{array}$ & {$[26]$} \\
\hline \multirow[t]{5}{*}{ Security } & $\begin{array}{l}\text { I am confident that the private financial information I provide with Social Network will be } \\
\text { secured }\end{array}$ & [27] \\
\hline & Using credit cards to purchase from this Social Network is safe & \\
\hline & In general, making payments online in Social Network is risk free. & \\
\hline & I think this Social Network shows great concern for the security of any transactions & \\
\hline & I think this Social Network has mechanisms to ensure the safe transmission of its financial & \\
\hline
\end{tabular}




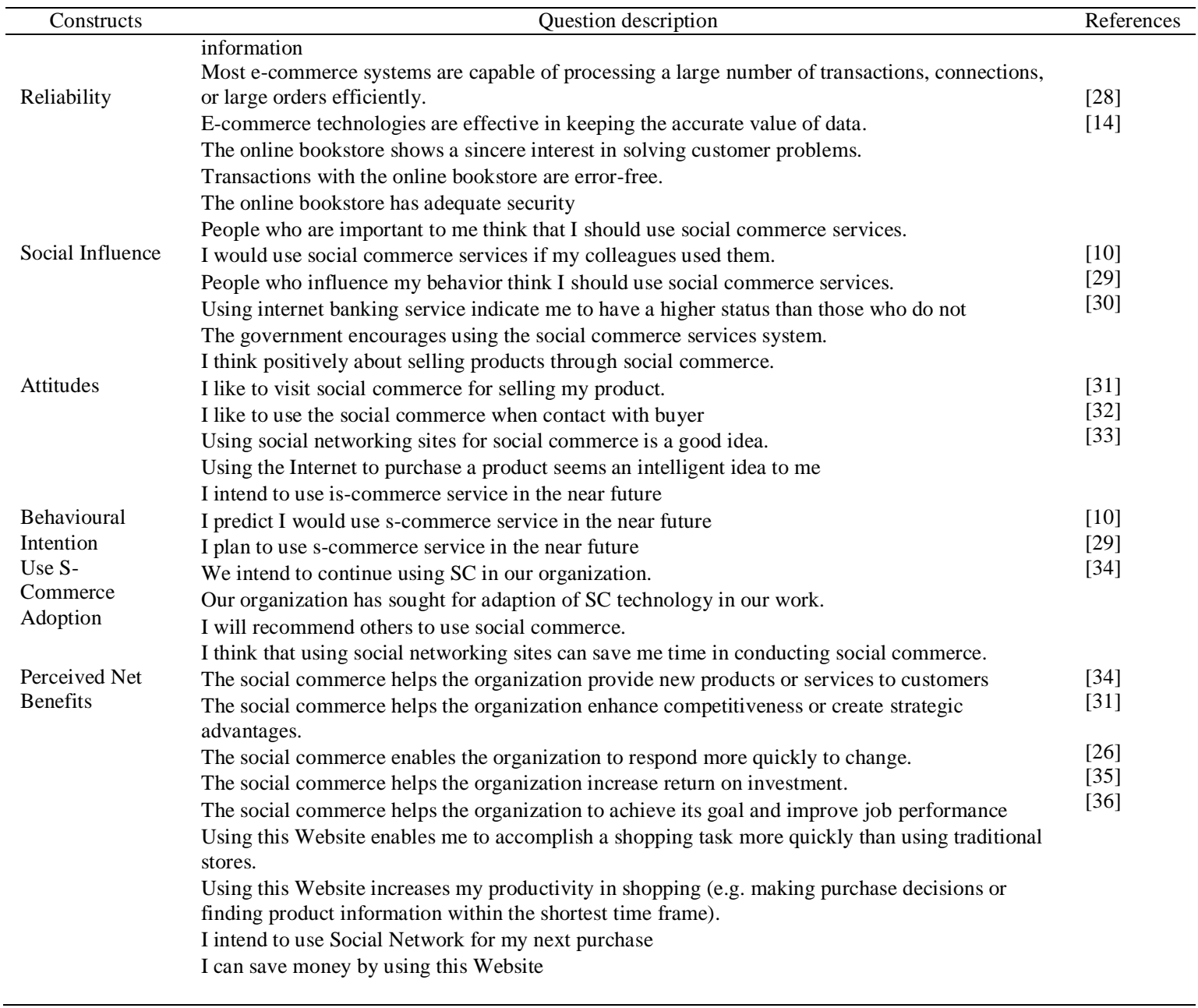

\section{RESULTS AND ANALYSIS}

Partial least squares (PLS) technique through the SmartPLS 2.0 software was applied to analyse the data collected. Components-based structural equation modeling (SEM) such as PLS is rapidly becoming a widely-used alternative to covariance-based SEM. The data analysis was conducted with SPSS version 22 and Smart PLS version 2. Specifically, the sample's descriptive statistics were obtained through the former software. On the other hand, following the suggestion of [37], a two-step analysis approach was adopted in analyzing the data, whereby the measurement model was first estimated prior to assessing the structural model.

\subsection{Descriptive Statistics}

The current study used a descriptive analysis of the profile of the participants. This type of analysis is conducted at the early stage of any data analysis prior to carrying out other types of statistical analyses. In this study, the respondents' characteristics are important since they provide better insights into or information of the study population. In the current study, a number of 100 questionnaires were distributed to the Malaysia SMEs in Selangor in the year of 2018. However, only 45 questionnaires were collected. From the collected questionnaires, for pilot study only 45 questionnaires were analysed.

These results show that the majority of the respondents were females in this study. Moreover, the results showed that in terms of their age, most of the respondents were at the age group of over 40 years. Mainly, the respondents held Bachelor degree. Furthermore, the descriptive analysis reveals that the majority of the population (95.6\%) was represented by those small size enterprises having 4-19 employees. The reason behind this higher response rate is due to the greater number of small medium enterprise operating in Selangor Malaysia, the targeted areas where the data was collected for this study.

As seen in Table 2, [38]pointed out that the acceptable value of Cronbach's alpha coefficient is 0.70 or above for an instrument to be considered reliable. The results confirmed that all scales met the required Cronbach's alpha (0.70) and above ). The results are shown in Table 3. The Cronbach's alpha value is 0.960 , 
which is indicative of the excellent reliability. The results confirmed that all items be 0.978 above 0.70 the result is Excellent According to [38].

Table 2. Alpha Coefficient Ranges and Strength

\begin{tabular}{cc}
\hline Alpha Coefficient Range & Strength of Association \\
\hline$<0.6$ & Poor \\
$0.6-$ to $<0.7$ & Moderate \\
$0.7-$ to $<0.8$ & Good \\
0.8 - to $<0.9$ & Very good \\
$>0.9$ & Excellent \\
\hline
\end{tabular}

Table 3. Reliability Items Of The Questionnaire In Pilot Study

\begin{tabular}{cccc}
\hline & \multicolumn{2}{c}{ Pilot test of measurements $(\mathrm{n}=45)$} & \\
Variable No & Variables & No of Items & Cronbach's alpha \\
\hline 1 & Perceived Usefulness & 5 & 0.941 \\
2 & Social commerce service quality & 4 & 0.925 \\
3 & Compatibility & 5 & 0927 \\
4 & Information quality & 6 & 0.918 \\
5 & Top management support & 5 & 0.946 \\
6 & IT Readiness & 5 & 0.856 \\
7 & Financial support for adoption & 4 & 0.947 \\
\multicolumn{5}{r}{} & of social commerce & & \\
9 & Training & 5 & 0.917 \\
10 & Security & 5 & 0.936 \\
11 & Reliability & 4 & 0.894 \\
12 & Social Influence & 5 & 0.879 \\
13 & Attitudes & 5 & 0.923 \\
14 & Behavioural intention to use & 4 & 0.954 \\
& Social-commerce & & 0.972 \\
& NET Benefit & 5 & 0.978 \\
\hline
\end{tabular}

\subsection{Measurement Model}

The measurement model consists of relationships among the latent variables and their (item) indicators. It is necessary to first establish construct validity for the measurement model before assessing the structural model for hypothesis testing. Construct validity concerns the extent to which the indicators reflect their underlying constructs (latent variables). Items in the measurement model need to demonstrate sufficient convergent and discriminant validity as a condition for establishing construct validity. As recommended by [39],factor loadings, composite reliability and average variance extracted (AVE) were used to assess convergent validity. See in Table 4 lists the indicator loadings/weights, reliabilities and AVE for all the items listed in the model.

As shown in the Table 4, the CR values ranged from 0.911 to 0.0 .978 , while those of the Cronbach's alpha values were from 0.709to 0.967. Also, AVE values were above $(>0.5)$ All the above values are at the recommended threshold value of 0.70 . Moreover, in comparing the CR values with the Cronbach's alpha values, it is evident that $\mathrm{CR}$ is indeed a stronger measuring criterion for assessing the internal consistency reliability. Thus, the results of Cronbach's alpha and CR indicate that the investigated constructs of the current study have high levels of internal consistency reliability.

\section{CONCLUSION}

The present study aimed to examine the effects of technological, organizational, and trust factors on SC adoption among SMEs in Malaysia. In this study, 45 respondents were chosen from different levels of management to complete the questionnaire and provide their feedback in terms of their understanding of it. Their feedback was used to further refine the instrument and to guarantee its effectiveness in collecting data. The current study was proved to be reliable and valid. This is because the loadings of all investigated factors were above the recommended value 0.7 , thus showing that the indicator reliability was acceptable. The results also revealed that the values of the construct composite reliability and Cronbach's alpha exceeded the suggested value of 0.7 , thus implying that the internal consistency reliability was acceptable. Concerning the AVE of the constructs, they also exceeded the value of 0.5 suggested by previous research, indicating acceptable level of the convergent validity. 
Table 4. Results of Measurements Model-Convergent Validity

\begin{tabular}{|c|c|c|c|c|}
\hline Constructs & Items & Loading & AVE & $\mathrm{CR}$ \\
\hline \multirow[t]{5}{*}{ Perceived Usefulness } & PU1 & 0.922 & 0.809 & 0.955 \\
\hline & PU2 & 0.918 & & \\
\hline & PU3 & 0.871 & & \\
\hline & PU4 & 0.898 & & \\
\hline & PU5 & 0.887 & & \\
\hline \multirow[t]{4}{*}{ Social commerce service quality } & SCSQ1 & 0.894 & 0.816 & 0.947 \\
\hline & SCSQ2 & 0.914 & & \\
\hline & SCSQ3 & 0.925 & & \\
\hline & SCSQ4 & 0.881 & & \\
\hline \multirow[t]{5}{*}{ Compatibility } & CM1 & 0.842 & 0.775 & 0.945 \\
\hline & $\mathrm{CM} 2$ & 0.927 & & \\
\hline & CM3 & 0.899 & & \\
\hline & CM4 & 0.908 & & \\
\hline & CM5 & 0.821 & & \\
\hline \multirow[t]{6}{*}{ Information quality } & IQ1 & 0.864 & 0.709 & 0.936 \\
\hline & IQ2 & 0.864 & & \\
\hline & IQ3 & 0.791 & & \\
\hline & IQ4 & 0.820 & & \\
\hline & IQ5 & 0.841 & & \\
\hline & IQ6 & 0.871 & & \\
\hline \multirow[t]{5}{*}{ Top management support } & TMS1 & 0.924 & 0.822 & 0.958 \\
\hline & TMS2 & 0.918 & & \\
\hline & TM3 & 0.901 & & \\
\hline & TMS4 & 0.884 & & \\
\hline & TMS5 & 0.906 & & \\
\hline \multirow[t]{5}{*}{ IT Readiness } & ITR1 & 0.717 & 0.636 & 0.897 \\
\hline & ITR2 & 0.801 & & \\
\hline & ITR3 & 0.831 & & \\
\hline & ITR4 & 0.868 & & \\
\hline & ITR5 & 0.764 & & \\
\hline \multirow[t]{4}{*}{ Financial support for adoption of social commerce } & FS1 & 0.921 & 0.861 & 0.961 \\
\hline & FS2 & 0.937 & & \\
\hline & FS3 & 0.919 & & \\
\hline & FS4 & 0.935 & & \\
\hline \multirow[t]{5}{*}{ Training } & $\mathrm{T} 1$ & 0.676 & 0.755 & 0.938 \\
\hline & $\mathrm{T} 2$ & 0.921 & & \\
\hline & $\mathrm{T} 3$ & 0.930 & & \\
\hline & $\mathrm{T} 4$ & 0.896 & & \\
\hline & T5 & 0.895 & & \\
\hline \multirow[t]{5}{*}{ Security } & $\mathrm{S} 1$ & 0.883 & 0.792 & 0.950 \\
\hline & $\mathrm{S} 2$ & 0.895 & & \\
\hline & S3 & 0.847 & & \\
\hline & $\mathrm{S} 4$ & 0.879 & & \\
\hline & S5 & 0.941 & & \\
\hline \multirow[t]{4}{*}{ Reliability } & $\mathrm{R} 1$ & 0.880 & 0.748 & 0.922 \\
\hline & $\mathrm{R} 2$ & 0.901 & & \\
\hline & R3 & 0.807 & & \\
\hline & $\mathrm{R} 4$ & 0.868 & & \\
\hline \multirow[t]{5}{*}{ Social Influence } & SI1 & 0.854 & 0.672 & 0.911 \\
\hline & $\mathrm{SI} 2$ & 0.709 & & \\
\hline & $\mathrm{SI} 3$ & 0.889 & & \\
\hline & SI4 & 0.840 & & \\
\hline & SI5 & 0.795 & & \\
\hline \multirow[t]{5}{*}{ Attitudes } & AT1 & 0.823 & 0.764 & 0.942 \\
\hline & AT2 & 0.834 & & \\
\hline & AT3 & 0.924 & & \\
\hline & AT4 & 0.899 & & \\
\hline & AT5 & 0.887 & & \\
\hline \multirow[t]{4}{*}{ Behavioural intention to use social-commerce } & BI1 & 0.903 & 0.879 & 0.967 \\
\hline & $\mathrm{BI} 2$ & 0.950 & & \\
\hline & $\mathrm{BI} 3$ & 0.943 & & \\
\hline & $\mathrm{BI} 4$ & 0.953 & & \\
\hline NET Benefit & NB1 & 0.947 & 0.898 & 0.978 \\
\hline & NB2 & 0.951 & & \\
\hline & NB3 & 0.918 & & \\
\hline & NB4 & 0.956 & & \\
\hline & NB5 & 0.967 & & \\
\hline
\end{tabular}

- Factor Loadings $(>0.7)$

- Composite reliability $(\mathrm{CR}>0.7)$

- Average variance extracted AVE $(>0.5)$ 


\section{ACKNOWLEDGEMENTS}

The author would like to thank the National University of Malaysia (UKM) for funding this research under research grant, FRGS/2/2014/ICT01/UKM/02/.

\section{REFERENCES}

[1] A. B. Hajira Be and R. Balasubramanian, Developing an Enhanced High-Speed Key Transmission (EHSKT) Technique to Avoid Fraud Activity in E-Commerce. 2018, pp. 1187-1194.

[2] N. Hajli, J. Sims, and M. Shanmugam, "A practical model for e-commerce adoption in Iran," Journal of Enterprise Information Management, vol. 27, no. 6, pp. 719-730, 2014.

[3] L. Zhou, P. Zhang, and H.-D. Zimmermann, "Social commerce research: An integrated view," Electronic Commerce Research and Applications, vol. 12, no. 2, pp. 61-68, 2013.

[4] G. Saibaba and P. Vaidya Sanivarapu, Developing an Userfriendly Online Shopping Web-Site. 2018, pp. 11261131.

[5] Z. Huang and M. Benyoucef, "From e-commerce to social commerce: A close look at design features," Electronic Commerce Research and Applications, vol. 12, no. 4, pp. 246-259, 2013.

[6] S. Z. Ahmad, A. R. Abu Bakar, T. M. Faziharudean, and K. A. Mohamad Zaki, "An empirical study of factors affecting e-commerce adoption among small-and medium-sized enterprises in a developing country: Evidence from Malaysia," Information Technology for Development, vol. 21, no. 4, pp. 555-572, 2015.

[7] N. A. Hashim, S. M. Nor, and H. Janor, "Riding the waves of social commerce: An empirical study of Malaysian entrepreneurs," Geografia-Malaysian Journal of Society and Space, vol. 12, no. 2, 2017.

[8] M. Luthfihadi and W. Dhewanto, "Technology Acceptance of E-commerce in Indonesia," International Journal of Engineering Innovation and Management, vol. 3, pp. 9-18, 2013.

[9] M. Shanmugam, v. karunakaran, and A. Amidi, Formulation Of An Integrated Social Commerce Framework To Promote Social Capital For Energy Sectors. 2018.

[10] V. Venkatesh, M. G. Morris, G. B. Davis, and F. D. Davis, "User acceptance of information technology: Toward a unified view," MIS quarterly, pp. 425-478, 2003.

[11] A. Goswami and S. Dutta, "E-Commerce Adoption by Women Entrepreneurs in India: An Application of the UTAUT Model," Business and Economic Research, vol. 6, no. 2, pp. 440-454, 2017.

[12] Y. Bai, Z. Yao, and Y.-F. Dou, "Effect of social commerce factors on user purchase behavior: An empirical investigation from renren. com," International Journal of Information Management, vol. 35, no. 5, pp. 538-550, 2015.

[13] P. Lal, "Analyzing determinants influencing an individual's intention to use social commerce website," Future Business Journal, vol. 3, no. 1, pp. 70-85, 2017.

[14] G.-G. Lee and H.-F. Lin, "Customer perceptions of e-service quality in online shopping," International Journal of Retail \& Distribution Management, vol. 33, no. 2, pp. 161-176, 2005.

[15] M. Cao, Q. Zhang, and J. Seydel, "B2C e-commerce web site quality: an empirical examination," Industrial Management \& Data Systems, vol. 105, no. 5, pp. 645-661, 2005.

[16] T.-P. Liang, Y.-T. Ho, Y.-W. Li, and E. Turban, "What drives social commerce: The role of social support and relationship quality," International Journal of Electronic Commerce, vol. 16, no. 2, pp. 69-90, 2011.

[17] D. H. McKnight, V. Choudhury, and C. Kacmar, "Developing and validating trust measures for e-commerce: An integrative typology," Information systems research, vol. 13, no. 3, pp. 334-359, 2002.

[18] S. Kim and H. Park, "Effects of various characteristics of social commerce (s-commerce) on consumers' trust and trust performance," International Journal of Information Management, vol. 33, no. 2, pp. 318-332, 2013.

[19] S. Poelmans, P. Wessa, K. Milis, E. Bloemen, and C. Doom, "Usability and acceptance of e-learning in statistics education, based on the compendium platform," in Proceedings of the International Conference of Education, Research and Innovation, 2008, pp. 1-10.

[20] D. K. Maduku, M. Mpinganjira, and H. Duh, "Understanding mobile marketing adoption intention by South African SMEs: A multi-perspective framework," International Journal of Information Management, vol. 36, no. 5, pp. 711-723, 2016.

[21] H. Gangwar, H. Date, and R. Ramaswamy, "Understanding determinants of cloud computing adoption using an integrated TAM-TOE model," Journal of Enterprise Information Management, vol. 28, no. 1, pp. 107-130, 2015.

[22] Y.-F. Kuo, C.-M. Wu, and W.-J. Deng, "The relationships among service quality, perceived value, customer satisfaction, and post-purchase intention in mobile value-added services," Computers in human behavior, vol. 25, no. 4, pp. 887-896, 2009.

[23] M. Hajli, "An integrated model for E-commerce adoption at the customer level with the impact of social commerce," International Journal of Information Science and Management (IJISM), pp. 77-97, 2012.

[24] M. Dashti, A. Sanayei, H. R. Dolatabadi, and M. H. Moshrefjavadi, "An Analysis of Factors Affecting Intention to Purchase Products and Services in Social Commerce," Modern Applied Science, vol. 10, no. 12, p. 98, 2016.

[25] Y. Wang and M. Hajli, "Co-creation in branding through social commerce: The role of social support, relationship quality and privacy concerns," 2014.

[26] S. Sharma, P. Menard, and L. A. Mutchler, "Who to Trust? Applying Trust to Social Commerce," Journal of Computer Information Systems, pp. 1-11, 2017.

[27] S. T. Alharbi, "Trust and acceptance of cloud computing: A revised UTAUT model," in Computational Science and Computational Intelligence (CSCI), 2014 International Conference on, 2014, vol. 2, pp. 131-134: IEEE. 
[28] B. J. Corbitt, T. Thanasankit, and H. Yi, "Trust and e-commerce: a study of consumer perceptions," Electronic commerce research and applications, vol. 2, no. 3, pp. 203-215, 2003.

[29] Y. S. Foon and B. C. Y. Fah, "Internet banking adoption in Kuala Lumpur: an application of UTAUT model," International Journal of Business and Management, vol. 6, no. 4, p. 161, 2011.

[30] A. Al Imarah, A. Zwain, and L. Al-Hakim, "The adoption of e-government services in the Iraqi Higher Education Context: An application of the UTAUT model in the University of Kufa," Journal of Information Engineering and Applications, vol. 3, no. 10, pp. 77-84, 2013.

[31] S.-Y. Hung, A. P.-I. Yu, and Y.-C. Chiu, "Investigating the factors influencing small online vendors' intention to continue engaging in social commerce," Journal of Organizational Computing and Electronic Commerce, vol. 28, no. 1, pp. 9-30, 2017.

[32] P. Palvia, "The role of trust in e-commerce relational exchange: A unified model," Information \& management, vol. 46, no. 4, pp. 213-220, 2009.

[33] B. Hernández, J. Jiménez, and M. J. Martín, "Customer behavior in electronic commerce: The moderating effect of e-purchasing experience," Journal of business research, vol. 63, no. 9-10, pp. 964-971, 2010.

[34] Y. K. Dwivedi, M. A. Shareef, A. C. Simintiras, B. Lal, and V. Weerakkody, "A generalised adoption model for services: A cross-country comparison of mobile health (m-health)," Government Information Quarterly, vol. 33, no. 1, pp. 174-187, 2016.

[35] D. J. Kim, D. L. Ferrin, and H. R. Rao, "Trust and satisfaction, two stepping stones for successful e-commerce relationships: A longitudinal exploration," Information systems research, vol. 20, no. 2, pp. 237-257, 2009.

[36] Y.-S. Wang, H.-Y. Wang, and D. Y. Shee, "Measuring e-learning systems success in an organizational context: Scale development and validation," Computers in Human Behavior, vol. 23, no. 4, pp. 1792-1808, 2007.

[37] J. C. Anderson and D. W. J. P. b. Gerbing, "Structural equation modeling in practice: A review and recommended two-step approach," vol. 103, no. 3, p. 411, 1988.

[38] J. F. Hair, "Research methods for business," 2007.

[39] J. F. Hair, W. C. Black, B. J. Babin, R. E. Anderson, R. L. J. P. P. H. N. J. h. C. Tatham, and r. J. o. A. Psychology, "Multivariate data analysis 6th Edition," vol. 87, pp. 49-74, 2006.

\section{BIOGRAPHIES OF AUTHORS}

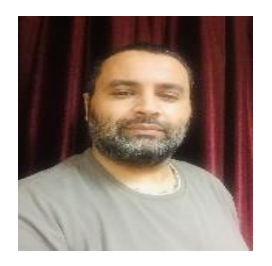

Walid Abdulla Ali is $\mathrm{PhD}$ student in the Faculty of Information Science and Technology, Universiti Kebangsaan Mlaysia (UKM). His reserch interst areas include soical commerce adoption among SMEs in Malaysia.

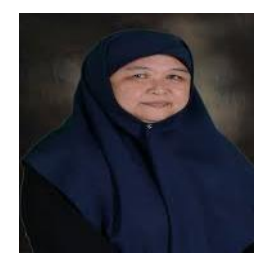

Muriati Muhktar is currently an Associate Professor at the Faculty of Information Science and Technology, Universiti Kebangsaan Malaysia (UKM) and a Head of Service Science Research Group. Her research interst focus on the Service Science, E-Supply Chain and Simulation and Modelling.

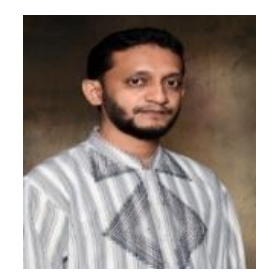

Ibrahim Mohamed is head of software engineering programme at the Faculty of Information Science and Technology, Universiti Kebangsaan Malaysia (UKM). His specialization is on the Accounting Information System, Business Process Modeling, IT Audit and Control. 